\title{
Accuracy of prenatal diagnosis of congenital cystic adenomatoid malformation
}

\author{
M McCullagh, I MacConnachie, D Garvie, E Dykes
}

\begin{abstract}
A series of 13 consecutive patients with a prenatal diagnosis of congenital cystic adenomatoid malformation (CCAM) were reviewed with respect to prenatal ultrasound findings, clinical features at birth, and postnatal outcome. In two cases $(15 \%)$ the abnormality regressed in utero. Only three infants $(23 \%)$ showed any respiratory distress at birth. After a mean of 25 months postnatal follow up, 11 patients $(85 \%)$ were found to have a definite pulmonary abnormality. In seven patients $(54 \%)$ the specific prenatal diagnosis of CCAM has been confirmed (five histologically, two radiologically). Four infants $(31 \%)$ were found to have other types of pulmonary abnormality and in two (15\%) the lungs remain apparently normal. Prenatal ultrasound appears reliable in the detection of pulmonary abnormalities but the variety of conditions identified postnatally suggests that specific prenatal diagnoses and prognoses should be avoided; prenatal counselling and perinatal management should be adapted accordingly.

(Arch Dis Child 1994; 71: F111-F113)
\end{abstract}

Antenatal ultrasound screening permits the prenatal detection of many fetal structural abnormalities and allows early parental counselling on the anticipated effects of the malformation. In some conditions, intervention by surgical techniques or even termination of the pregnancy may be recommended. The accuracy of the ultrasound diagnosis thus becomes of prime importance in determining the outcome for the fetus.

We have recently encountered a number of infants in whom a prenatal diagnosis of congenital cystic adenomatoid malformation of the lung (CCAM) had been made. The disparate postnatal findings in these babies prompted us to review the prenatal appearances, prognosis offered, and the ultimate outcome in each case.

\section{Methods}

All cases of CCAM referred to us as a consequence of prenatal ultrasound diagnosis were reviewed. In all cases the diagnosis was made or confirmed by a consultant in a tertiary fetal medicine centre. Details of the timing and reported appearance of the first ultrasound scan were recorded, along with those of any subsequent prenatal scans or interventions. All interventions were performed by an experienced fetal medicine specialist. The clinical condition of the infants at delivery and during the neonatal period was noted along with the results of any postnatal investigations or surgical procedures. When available, the prognosis initially offered to the parents at the time of the initial diagnosis was documented, along with the ultimate outcome.

\section{Results}

Between January 1991 and June 1993, 13 infants with a prenatal ultrasound diagnosis of CCAM were referred for postnatal management. In all cases we were notified of the diagnosis before delivery and arrangements were made for in utero transfer and delivery at a paediatric surgical centre.

The diagnosis of CCAM was made at a mean of 22 weeks' gestation (range 19-27 weeks). From the ultrasound reports, it appeared that a diagnosis of CCAM type I was made if a single large cyst was detected, while the diagnosis of CCAM type II was made if multiple cysts with or without echogenic areas were seen. The fetuses diagnosed to have

Table 1 Ultrasound features in 13 fetuses with a prenatal diagnosis of CCAM

Children's Hospital, Lewisham, London SE13 6LH, Department of Paediatric Surgery M McCullagh E Dykes

Department of Neonatology I MacConnachie D Garvie

Correspondence to: Miss McCullagh. Accepted 10 June 1994

\begin{tabular}{|c|c|c|c|c|c|c|c|c|}
\hline $\begin{array}{l}\text { Case } \\
\text { No }\end{array}$ & $\begin{array}{l}\text { Gestation } \\
\text { at diagnosis } \\
\text { (weeks) }\end{array}$ & $\begin{array}{l}\text { Diagnosis } \\
\text { made } \\
\text { (type) }\end{array}$ & $\begin{array}{l}\text { Affected } \\
\text { lobe }\end{array}$ & $\begin{array}{l}\text { Mediastinal } \\
\text { shift }\end{array}$ & $\begin{array}{l}\text { Pleural } \\
\text { effusion }\end{array}$ & $\begin{array}{l}\text { Polyhydramnios } \\
\text { present }\end{array}$ & $\begin{array}{l}\text { Shunt } \\
\text { inserted }\end{array}$ & $\begin{array}{l}\text { Prenatal } \\
\text { course }\end{array}$ \\
\hline $\begin{array}{r}1 \\
2 \\
3 \\
4 \\
5 \\
6 \\
7 \\
8 \\
9 \\
10 \\
11\end{array}$ & $\begin{array}{l}21 \\
21 \\
19 \\
26 \\
22 \\
31 \\
19 \\
20 \\
27 \\
21 \\
20\end{array}$ & $\begin{array}{l}\text { CCAM (II) } \\
\text { CCAM (I) } \\
\text { CCAM (I) } \\
\text { CCAM (II) } \\
\text { CCAM (II) } \\
\text { CCAM (III) } \\
\text { CCAM (I) } \\
\text { CCAM (II) } \\
\text { CCAM (III) } \\
\text { CCAM (I) } \\
\text { CCAM (III) }\end{array}$ & $\begin{array}{l}\text { Right lower } \\
\text { Left lower } \\
\text { Left upper } \\
\text { Right middle } \\
\text { Left lower } \\
\text { Left lower } \\
\text { Right middle } \\
\text { Right upper } \\
\text { Right lower } \\
\text { Left lower } \\
\text { Right upper and }\end{array}$ & $\begin{array}{l}\text { Yes } \\
\text { Yes } \\
\text { Yes } \\
\text { Yes } \\
\text { Yes } \\
\text { Yes } \\
\text { Yes } \\
\text { Yes } \\
\text { No } \\
\text { Yes }\end{array}$ & $\begin{array}{l}\text { No } \\
\text { No } \\
\text { No } \\
\text { No } \\
\text { No } \\
\text { Yes } \\
\text { No } \\
\text { No } \\
\text { No } \\
\text { No }\end{array}$ & $\begin{array}{l}\text { No } \\
\text { No } \\
\text { No } \\
\text { Yes } \\
\text { No } \\
\text { No } \\
\text { No } \\
\text { No } \\
\text { No } \\
\text { No }\end{array}$ & $\begin{array}{l}\text { No } \\
\text { No } \\
\text { No } \\
\text { Yes } \\
\text { Yes } \\
\text { Yes } \\
\text { Yes } \\
\text { No } \\
\text { No } \\
\text { No }\end{array}$ & $\begin{array}{l}\text { Persistent cysts } \\
\text { Persistent cyst } \\
\text { Lesion decreased } \\
\text { Mediastinal shift } \\
\text { Large cyst collapsed } \\
\text { Effusion reduced } \\
\text { Mediastinal shift } \\
\text { Lesion persisted } \\
\text { Lesion persisted } \\
\text { Lesion persisted }\end{array}$ \\
\hline $\begin{array}{l}12 \\
13\end{array}$ & $\begin{array}{l}20 \\
20\end{array}$ & $\begin{array}{l}\text { CCAM (II) } \\
\text { CCAM (II) }\end{array}$ & $\begin{array}{l}\text { middle } \\
\text { Left lower } \\
\text { Right lower }\end{array}$ & $\begin{array}{l}\text { Yes } \\
\text { No } \\
\text { Yes }\end{array}$ & $\begin{array}{l}\text { No } \\
\text { No } \\
\text { No }\end{array}$ & $\begin{array}{l}\text { Yes } \\
\text { No } \\
\text { No }\end{array}$ & $\begin{array}{l}\text { No } \\
\text { No } \\
\text { No }\end{array}$ & $\begin{array}{l}\text { Lesion persisted } \\
\text { Lesion persisted } \\
\text { Lesion resolved by } \\
\quad 30 \text { weeks }\end{array}$ \\
\hline
\end{tabular}


Table 2 Postnatal outcome in 13 infants diagnosed prenatally to have CCAM

\begin{tabular}{|c|c|c|c|c|c|c|}
\hline \multirow{2}{*}{$\begin{array}{l}\text { Case } \\
\text { No }\end{array}$} & \multicolumn{2}{|l|}{ Chest radiographs } & \multirow{2}{*}{$\begin{array}{l}\text { Ventilation perfusion } \\
\text { scan }\end{array}$} & \multirow[b]{2}{*}{ Postnatal management } & \multirow{2}{*}{$\begin{array}{l}\text { Follow } \\
\text { up } \\
\text { (months) }\end{array}$} & \multirow[b]{2}{*}{ Final diagnosis } \\
\hline & At birth & Subsequent preoperative & & & & \\
\hline $\begin{array}{l}1 \\
2\end{array}$ & $\begin{array}{l}\text { Large cysts } \\
\text { Cysts + mediastinal shift }\end{array}$ & $\begin{array}{l}\text { Unchanged } \\
\text { Unchanged }\end{array}$ & $\begin{array}{l}\text { Defect right lower lobe } \\
\text { Not done }\end{array}$ & $\begin{array}{l}\text { Excision sequestration at } 5 \text { weeks } \\
\text { Left lower lobectomy at } 2 \text { weeks for } \\
\text { persistent cysts on radiography }\end{array}$ & $\begin{array}{l}36 \\
28\end{array}$ & $\begin{array}{l}\text { Sequestration } \\
\text { CCAM type I }\end{array}$ \\
\hline 3 & Normal & Normal & Not done & Conservative. Remains well & 31 & Normal \\
\hline 4 & Cysts + mediastinal shift & Not done & Not done & $\begin{array}{l}\text { Right middle lobectomy at } 6 \text { hours } \\
\text { for respiratory distress }\end{array}$ & 20 & CCAM type I \\
\hline 5 & Cysts + mediastinal shift & Not done & Not done & $\begin{array}{l}\text { Left lower lobectomy at } 12 \text { hours for } \\
\text { respiratory distress }\end{array}$ & 41 & CCAM type I \\
\hline 6 & $\begin{array}{l}\text { Solid mass left } \\
\text { base }+ \text { effusion }\end{array}$ & Unchanged & Mismatch left lower lobe & Excision sequestration at 8 days & 29 & Sequestration \\
\hline 7 & Right upper zone mass & $\begin{array}{l}\text { Right upper lobe } \\
\text { consolidation }\end{array}$ & $\begin{array}{l}\text { Reduced perfusion + ventilation } \\
\text { to right apex }\end{array}$ & Right upper lobectomy at 5 weeks & 20 & $\begin{array}{l}\text { Primary pulmonary, } \\
\text { lobar hypoplasia }\end{array}$ \\
\hline 8 & $\begin{array}{l}\text { Right upper lobe } \\
\text { consolidation }\end{array}$ & Unchanged & Defect right upper lobe & Right upper lobectomy at 8 days & 21 & Bronchial atresia \\
\hline 9 & Normal & Normal & Normal & Conservative. Remains well & 29 & Normal \\
\hline 10 & Cysts left base & Cysts increased & Mismatch left lower lobe & Left lower lobectomy & 31 & CCAM type II \\
\hline 11 & Right upper lobe collapse & Cysts right upper lobe & Defect right upper lobe & Surgery deferred as asymptomatic & 21 & Probable CCAM \\
\hline 12 & Cysts left lower lobe & Cysts increased & $\begin{array}{l}\text { Reduced perfusion + ventilation } \\
\text { left lower lobe }\end{array}$ & Left lower lobectomy at 5 months & 18 & CCAM type I \\
\hline 13 & Normal & $\begin{array}{l}\text { Cystic change right } \\
\text { lower lobe }\end{array}$ & Not yet done & Conservative. Remains asymptomatic & 9 & Probable CCAM \\
\hline
\end{tabular}

CCAM type III were those in whom the abnormal area was purely echogenic, without a cystic component. The prenatal findings, diagnoses, and interventions are shown in table 1 .

In two cases $(15 \%)$ the abnormality regressed spontaneously in utero. In cases 4, 5, and 7 , thoracoamniotic shunts were inserted into the largest visible cyst at $26,32 \cdot 5$, and 22 weeks' gestation respectively, in an effort to ameliorate the mediastinal shift. In case 6 , a thoracoamniotic shunt was inserted at 31 weeks' gestation to relieve a pleural effusion surrounding a presumed CCAM type III lesion. A subsequent attempt at intervention in this patient was made at 33 weeks but the procedure was unsuccessful and was abandoned. Preterm delivery occurred in two of these four cases (cases 5 and 6 at 33 and 34 weeks' gestation respectively); all other infants were delivered at term.

All infants were in good condition at birth. Three babies (cases 2, 4, and 5) became tachypnoeic within six hours of birth; two were electively ventilated before surgery (cases 4 and 5) and one was maintained on headbox oxygen. All other infants remained well breathing spontaneously in air.

The results of initial and subsequent investigations and surgery are shown in table 2. Four children $(31 \%)$ remain well without surgical intervention at 9-41 months of age (mean follow up $25 \cdot 7$ months). In two of these cases all postnatal investigations were normal; computed tomography was not performed as it was considered unjustifiable to subject the infants to the general anaesthesia which would have been required. The parents of one of these infants had been offered a termination at 19 weeks because of the prenatal ultrasound diagnosis. In the other two cases, despite persistent radiological abnormality, surgical intervention has been deferred at the parents' request because the children are asymptomatic. The parents of one of these infants were also advised to terminate the pregnancy because of the poor prognosis. The nine remaining patients have undergone surgical excision of the affected lobe. In only two cases
(15\%) was the operation required urgently because of symptoms; in the remaining seven patients surgery was performed because of persisting radiological abnormality.

The postnatal diagnosis and outcome in each case are shown in table 2. Overall, the prenatal ultrasound diagnosis of CCAM was confirmed to be correct in five cases $(38 \%)$, remains unproved but likely in two $(15 \%)$, and was erroneous in six cases (46\%). There appeared to be no relationship between any specific prenatal features and the final postnatal diagnoses.

\section{Discussion}

The improved definition of current ultrasound technology and its routine use in antenatal care has permitted the early visualisation of most fetal organs and the identification of many structural abnormalities. Sequential scanning has also offered an unprecedented opportunity to observe the natural evolution of many of these abnormalities. In several conditions, experience has shown that the early fetal appearances may not reflect the ultimate postnatal outcome and that the traditionally held beliefs on appropriate treatment may be unsubstantiated.

CCAM is one of a number of congenital pulmonary abnormalities in which cyst formation occurs. It is characterised by a multicystic mass of tissue in which bronchial structures proliferate. ${ }^{1}$ The cyst walls contain excessive elastic tissue and smooth muscle, and the number and size of the cysts allows further classification into the well recognised Stocker types I, II, and III (microcystic). ${ }^{2}$

Other cystic lesions include sequestration, bronchogenic cyst, and congenital lobar emphysema. Although several studies have demonstrated a number of common features in these conditions, suggesting a similar developmental origin, 134 clinicians continue to differentiate between these anomalies on the basis of symptomatology and radiological appearances. 56

The clinical features which have been retrospectively associated with pathologically 
proved CCAM include neonatal respiratory distress ( $85 \%$ of cases) which often requires urgent surgery. ${ }^{5}$ Mortality is highest in those lesions classified pathologically as CCAM type III. ${ }^{6}$ In contrast, the majority of pulmonary sequestrations and bronchogenic cysts classically present in later childhood with symptoms other than respiratory distress. ${ }^{1}$ A small proportion of cases of CCAM have been discovered incidentally in asymptomatic children $^{5}$ and malignant change has been reported in unsuspected lesions. ${ }^{7}$ These retrospective associations have led to the belief that patients with CCAM require early surgery, usually for life threatening symptoms, and that all untreated cases will result in infection or more serious complications if left in situ.

The advent of prenatal ultrasound has allowed obstetricians to observe 'cystic' lung changes in many fetuses early in gestation. 689 The appearances of these fetal lungs are often similar to the postnatal radiological appearances of lungs which have been classified pathologically (after resection of the offending lesion) as CCAM. Consequently the obstetrician, in good faith, may ascribe a prenatal diagnosis of CCAM to a fetus, thus beginning a cascade of parental counselling and treatment based on beliefs arising from experience of cases which presented clinically postnatally.

This series of patients demonstrates that fetal lung abnormalities may have many causes. Although evident as early as 20 weeks' gestation, 'cysts' may regress or even disappear completely during pregnancy. Of those which persist, only a few appear to be symptomatic at birth, and the spectrum of diagnoses identified postnatally is wide. Thus, although prenatal ultrasound appears to be a sensitive method of detecting a pulmonary abnormality, it should be recognised that there are no specific ultrasonographic features from which a reliable prenatal diagnosis of CCAM can be made.

Consequently, if a prenatal diagnosis of pulmonary cystic abnormality is made in the fetus, counselling and treatment must be modified accordingly. No specific diagnosis should be given, but the parents should be told that some cystic change has been observed and that further monitoring will be necessary. The differential diagnosis should be considered carefully and no action taken which might jeopardise the outcome of a benign condition. A careful search for other abnormalities should be made, and only serious problems such as large effusions or hydrops should be considered for prenatal intervention. 810

Sequential observation of the fetus will reveal whether the lesion is regressing or increasing in size, and only then can appropriate arrangements for delivery be made. Those infants with large cysts and/or mediastinal shift persisting to late gestation should be delivered in a neonatal surgical centre so that urgent surgery can be readily performed if required. In all cases, even those who are asymptomatic at birth, further investigations and follow up are required in order to ensure that late complications do not occur. Multidisciplinary input during the prenatal course is essential if such arrangements are to proceed smoothly.

Only after careful long term observation and documentation of large series of patients will it become clear whether it is possible to distinguish specific malformations prenatally. Obstetricians and fetal medicine specialists should not be tempted to give a prognosis for a fetal pulmonary abnormality based on the published postnatal retrospective experience. Similarly, paediatricians and paediatric surgeons who are informed of a prenatal diagnosis of CCAM or any other specific cystic lung abnormality should be aware that such diagnoses are unreliable and should ensure that the subsequent counselling, investigation, and treatment take account of this fact. All fetuses suspected to have a pulmonary lesion should be referred to a centre with sufficient expertise in both prenatal and postnatal management of pulmonary abnormalities to ensure that the parents receive accurate information from which they can make an informed decision regarding their pregnancy.

1 Buntain WL, Isaacs $H$, Payne VC, Lindesmith GG, Rosenkrantz JG. Lobar emphysema, cystic adenomatoid malformation, pulmonary sequestration and bronchogenic cyst in infancy and childhood: a clinical group. f Pediatr Surg 1974; 9: 85-93.

2 Stocker JT, Madewell JE, Drake RM. Congenital cystic adenomatoid malformation of the lung: classification and morphologic spectrum. Hum Pathol 1977; 8: 155-71.

3 Demos NJ, Teresi A. Congenital lung malformations: a unified concept and case report. $\mathcal{f}$ Thoracic Cardiovasc unified concept and cast

4 Clements BS, Warner JO, Shinebourne EA. Congenital bronchopulmonary vascular malformations; clinical application of a simple anatomical approach in 25 cases. Thorax 1987; 42: 409-16.

5 Nishibayashi SW, Andrassy RJ, Woolley MM. Congenital cystic adenomatoid malformation: a 30 year experience. f Pediatr Surg 1981; 16: 704-6.

6 Neilson IR, Russo P, Laberge J-M, et al. Congenital adenomatoid malformation of the lung: current management and prognosis. $\mathcal{F}$ Pediatr Surg 1991; 26: 975-81.

7 Ueda K, Gruppo R, Unger F, Martin L, Bove K. Rhabdomyosarcoma of lung arising in congenital adenomatoid malformation. Cancer 1977; 40: 383-8.

8 Adzick NS, Harrison MR, Glick PL, et al. Fetal cystic adenomatoid malformation: prenatal diagnosis and adenomatoid malformation: prenatal diagn

9 Revillon Y, Jan D, Plattner V, et al. Congenital cystic malformation of the lung: prenatal management and prognosis. $₹$ Pediatr Surg 1993; 28: 1009-11.

10 Adzick NS. Fetal thoracic lesions. Seminars in Pediatric Surgery 1993; 2: 103-8. 